\title{
sciendo
}

CIVIL AND ENVIRONMENTAL ENGINEERING REPORTS

E-ISSN 2450-8594

CEER 2018; 28 (3): 090-102

DOI: $10.2478 /$ ceer-2018-0037

Original Research Article

\section{NUMERICAL ANALYSIS OF THE FLEXURAL RESPONSE OF RC BEAMS STRENGTHENED WITH NSM-CFRP}

\author{
Ahmed KHENE ${ }^{1}$, Habib Abdelhak MESBAH ${ }^{2}$, Nasr-Eddine CHIKH ${ }^{3}$ \\ ${ }^{1,3}$ University of Mentouri, Algeria \\ ${ }^{2}$ University of Rennes, France
}

\begin{abstract}
In this study, we have chosen to use a new technique of reinforcement with composite materials, namely the near surface mounted technique (NSM). The NSM technique consists in inserting strips of carbon fiber reinforced polymer (CFRP) laminate into slits made beforehand at the level of the concrete coating of the elements to be reinforced. A numerical investigation was conducted on rectangular reinforced concrete beams reinforced with NSM-CFRP using the ATENA finite element code. A parametric study was also carried out in this research. The numerical results were compared with the experimental results of the beams tested by other researchers with the same reinforcement configurations. Overall, numerical behavior laws are rather well-suited to those obtained experimentally and the parametric study has also yielded interesting results.
\end{abstract}

Keywords: NSM, Strengthening, CFRP, Numerical Analysis, RC Beams

\footnotetext{
${ }^{1}$ Corresponding author: Numerical Analysis of the Flexural Response of RC Beams Strengthened with NSM-CFRP, University of Mentouri Constantine 1, Civil Engineering Department (L.M.D.C.), Constantine 25000, Algeria, tel. +213550284317, e-mail: ahmed.khene@ yahoo.fr

${ }^{2}$ Civil Engineering Department (L.G.C.G.M.), University of Rennes 1, Rennes 35704 - Cedex 07, France
} 


\section{INTRODUCTION}

Composite materials or fiber reinforced polymers can generally be defined as the combination of two or more materials. The final assembly of the constituents having interesting characteristics. The fiber reinforced polymers are now commonly referred to as reinforcements which are embedded in an epoxy matrix whose mechanical strength is much lower. These materials are in the form of bars, strips or sheets. They can be manufactured from a pultrusion procedure from carbon fiber, glass or aramid to obtain at the end of the CFRP, GFRP and AFRP, respectively. The strengthening of reinforced concrete beams by composite materials includes several techniques. Among the most effective techniques, mention may be made of the technique of reinforcement by insertion of PRFs, called the technique near surface mounted and that of reinforcement by adhesive reinforcement on the surface Externally Bonded Reinforcement.

Reinforcement with carbon fiber reinforced polymers using the NSM technique has been the subject of extensive research by numerous authors: (El-Hacha [1], Kotynia [2], Soliman [3], Al-Mahmoud [4], Hong [5], Mostofinejad [6], Sharaky [7] and Haddad [8]). The results have shown the efficiency of the NSM technique in the increasing the bearing capacity of the beams as well as improving their overall behavior. To fully understand the behavior and explore the benefits of reinforced concrete beams strengthened with a carbon fiber reinforced polymer (CFRP), the structural response of the system must be invested for different conditions. However, the experimental study of the system for all its aspects of behavior will be expensive. The development of high-speed computers and more sophisticated non-linear hardware models, capable of simulating exactly and predicting what will happen experimentally, has contributed to this transition. The purpose of beam modeling is to reduce the amount of experimental work and save money while conducting several theoretical research on the system with different configurations. Studies have shown that the use of a 2D approach for finite element analysis leads to a faster and less expensive calculation than a 3D approach, while at the same time leading to interesting results with reasonable accuracy. In this study, a 2D nonlinear finite element model is used to predict the load capacity and response of reinforced concrete beams reinforced by CFRP bands using the NSM method. The models were tested by a 4-point bending test using the finite element code ATENA [9]. The modeling predicted the behavior of RC beams reinforced by integrated CFRP plates loaded to failure. The results were verified by comparing them with those obtained experimentally by Hongseob [10]. The results proved the practicality and validity of the finite element method in the modeling RC beams strengthened in flexure using NSM-CFRP strips reinforcement. 
In the parametric study, a total of 12 models are constructed and analyzed numerically to study the effect of using different CFRP reinforcement ratios with a variation in the diameter of longitudinal steels and the number of CFRP bands. This is to see the flexural performance of the reinforced beams. A parametric study was conducted to evaluate the effect of some factors on the overall structural response of the RC beam.

\section{BEAMS CONFIGURATIONS AND TESTING DEVICE}

The numerical analysis presented here is based on experimental data obtained by Hongseob [10] that evaluates the response of reinforced RC members with NSM-CFRP bands. All specimens were subjected to a monotonous four-point bending test until failure. The parameters considered in our study are the ratio of CFRP reinforcement (Af/As), with the variation of the number of CFRPs and the number of the lower steel reinforcements of the beams. The numerical program consisted of six unreinforced reference RC beams and six reinforced RC beams. The beams have a length of $3000 \mathrm{~mm}$, with a section of $250 \mathrm{~mm}$ wide and $400 \mathrm{~mm}$ high. With regard to the boundary conditions of the test device, the beams are supported on two sides with a span of $2700 \mathrm{~mm}$ and two loading points spaced $160 \mathrm{~mm}$ apart at the center of the beams. Two groups of beams are distinguished in this investigation. The first group with two longitudinal reinforcements of $16 \mathrm{~mm}$ in diameter in the lower part of the beam and with two bars of $10 \mathrm{~mm}$ at the top of the beam. On the other hand, the second group is distinguished with three longitudinal reinforcement at the lower part of the same diameter as the first group and also with the same configuration concerning the compression reinforcement. And the third group with three longitudinal reinforcements lower than $14 \mathrm{~mm}$ in diameter. The transverse reinforcements have a diameter of $10 \mathrm{~mm}$ and a spacing of $100 \mathrm{~mm}$. The beams have a coating of the order of $40 \mathrm{~mm}$ and the concrete used is a concrete with a compressive strength of $30 \mathrm{MPa}$ at 28 days. The steel rebars have Young's modulus of $200 \mathrm{GPa}$ and a yield strength of $350 \mathrm{MPa}$. CFRP plates used have a rectangular cross-section $2.5 \mathrm{~mm}$ wide and $1.2 \mathrm{~mm}$ deep. The beams are designated $\mathrm{Bx} \_\mathrm{xA} \emptyset-\mathrm{xS}$. The meaning of the different letters is as follows: for example, the sample B12_2A16-3S designates the number 12 beam with two lower reinforcements steel of $16 \mathrm{~mm}$ diameter, reinforced with 03 CFRP Strips. Figure 1 shows the details of the positioning of the CFRP strips in the longitudinal section of the reinforced concrete beams. Figure 2 illustrates an example of B12_2A16-3S beam cross-section details and the other beam configurations are shown in Table 2. The method used during the test is a fourpoint loading. The results demonstrated that the use of carbon fiber reinforced polymers with the near surface mounted technique could significantly improve 
the flexural performance of $\mathrm{RC}$ beams by increasing their ultimate load capacities and thereby limiting deflection to mid-span of the beams. The mechanical properties of carbon fiber reinforced polymer and epoxy resin are shown in Table 1.

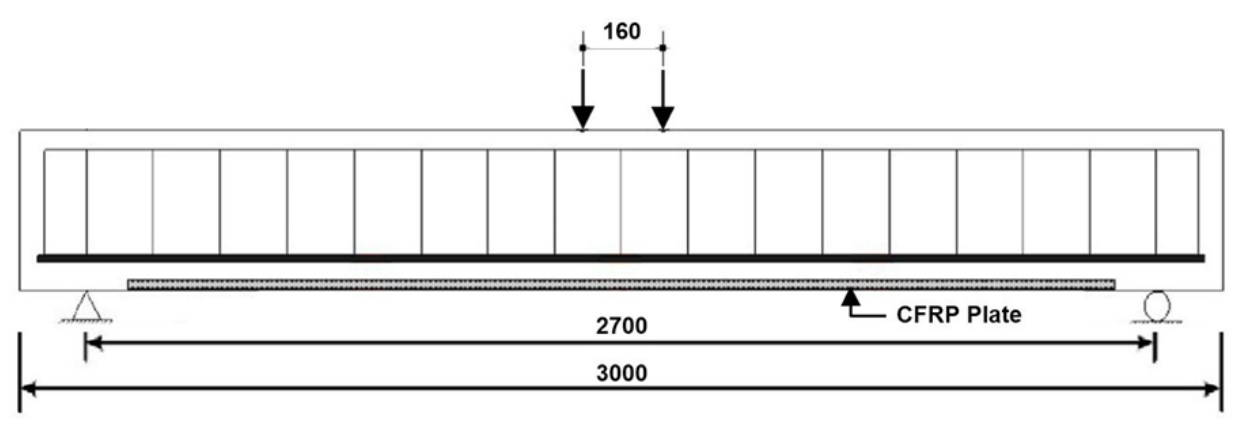

Fig. 1. Geometric characteristics and positioning of beam reinforcement (mm)

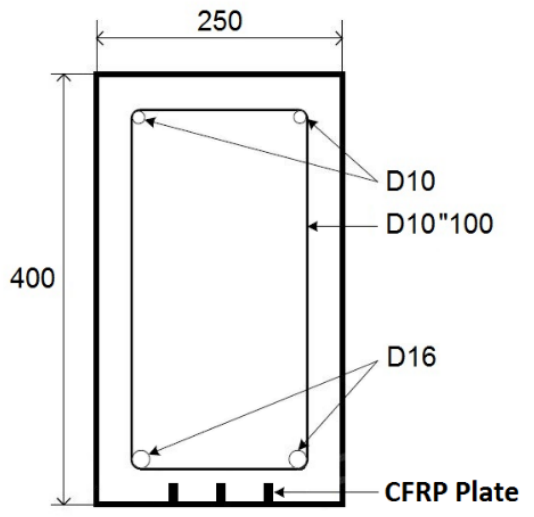

Fig. 2. Example of cross-sectional details of B12_2A16-3S beam (mm)

Table 1. Mechanical properties of CFRPs and epoxy resin

\begin{tabular}{|c|l|c|c|}
\hline \multirow{2}{*}{ CFRP } & Tensile Strength & Results & Unit \\
\cline { 2 - 4 } & Modulus of Elastic & 3160 & $\mathrm{MPa}$ \\
\hline \multirow{3}{*}{ Epoxy resin } & Tensile strength & 165 & $\mathrm{GPa}$ \\
\cline { 2 - 4 } & Compressive strength & 25.7 & $\mathrm{MPa}$ \\
\cline { 2 - 4 } & Modulus of elasticity & 85.6 & $\mathrm{MPa}$ \\
\hline
\end{tabular}




\section{NUMERICAL VALIDATION AND PARAMETRIC STUDY}

The fracture model used in the ATENA code is based on the classical orthotropic crack model. The modeling of the concrete is carried out with 2D non-linear cementitious elements with a model of plastic rupture indicated in Fig.3. The modeling of the reinforcements steel was made according to the law of bilinear behavior illustrated in Fig.4.(a) and the CFRP bands undergo linear elastic behavior until failure the relationship is shown in Fig.4.(b) For finite element modeling of concrete and steel reinforcement, the values of the measured characteristics given in point 2 have been adopted. On the other hand, for carbon fiber reinforced polymers and resin, the values provided by the manufacturer have been taken into account and are detailed in Table 1.

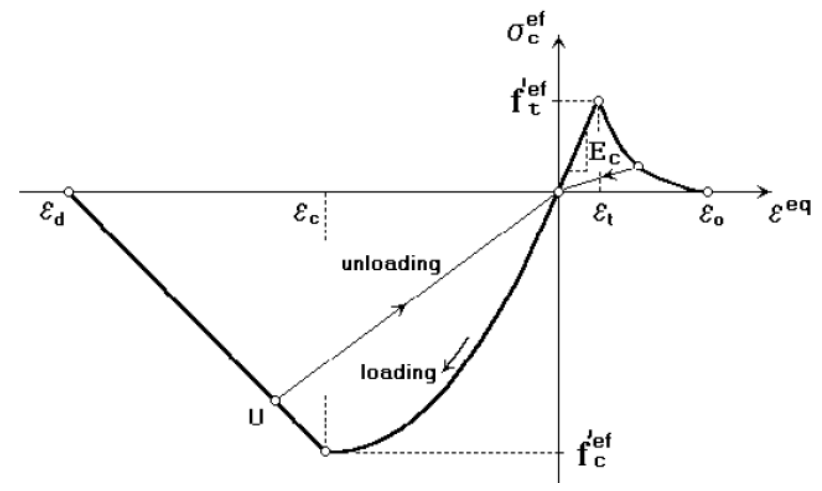

Fig. 3. Stress-strain relationship of concrete

(a)

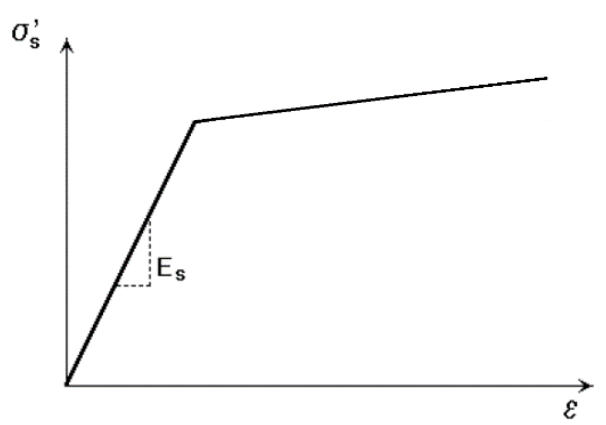

(b)

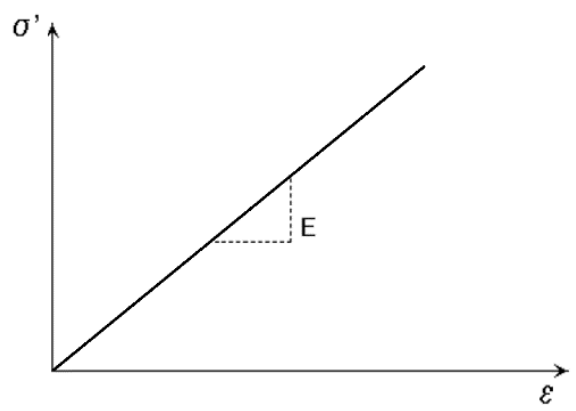

Fig. 4. (a) The bilinear stress-strain law of reinforcements steel and (b) uniaxial stressstrain curve of CFRPs

For the FE models, we introduced to mesh with a density of the order $0.05 \mathrm{~m}$. The mesh of the mid-span of the RC beam is represented in Fig.5. Concerning the stress, the deformation was imposed for the model FE and we adopted the 
incrementation step by step. As the beam is symmetrical, the modeling was carried out only on half of the beam while replacing the other half with appropriate boundary conditions at the central section of symmetry. Where the horizontal displacements along this line are equal to zero, the vertical movement is blocked for the support. The developed FE model considers the non-linearities of the materials used, with the consideration that the CFRP-Concrete bond is perfect. To evaluate the EF models developed and test their validity, a comparison between the results of finite element numerical simulations and experimental results of Hongseob [10] was performed. In previous work models [11] and in addition to this study, the results clearly show good agreement between the predicted FE numerical simulations and the experimental records at all loading stages until failure the control and the NSM-CFRP retrofitted beams. Therefore, the developed model is able to perform precise parametric studies with different configurations.

In this parametric study the cross-section of CFRP laminates (Af) applied in the beam of each group was evaluated to increase The ultimate load of the corresponding reference beam. The number of CFRP strip was varied from one, two and three strips. The number of lower longitudinal steel bars was also varied from two to three bars. And the diameter of the steel bars varied from 14 to 16 $\mathrm{mm}$, illustrated in Fig.2. These parameters were chosen to have six (Af/As) ratios ranging from 7.46 to $22.38 \%$. Table 2 shows the details of the parametric configuration of the beams.

The comparison of the experimental measurements with the simulation FE of the average load deflection response for the beams is shown in Fig.6. and the gains of the resistances of the beams are mentioned in Table 3. The maximum difference between the experimental results and the predicted numerical results for the ultimate load is less than $17 \%$ for all specimens, while for the final deviation it does not exceed $20 \%$. The developed digital FE model was then used to examine the behavior of beams that were not fabricated and tested experimentally.

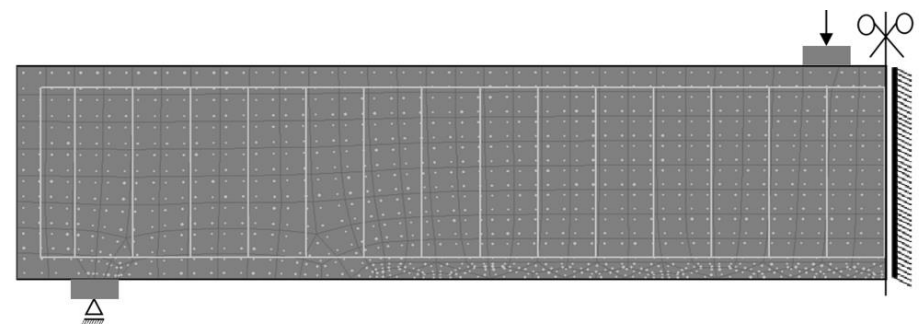

Fig. 5. The mid-span model of the reinforced concrete beam 
Table 2. Details of parametric study model configurations

\begin{tabular}{|c|c|c|c|c|c|c|c|c|}
\hline \multirow[b]{2}{*}{ Group } & \multirow[b]{2}{*}{$\begin{array}{l}\text { Specimen } \\
\text { designation }\end{array}$} & \multirow{2}{*}{ 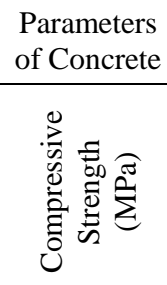 } & \multicolumn{2}{|c|}{$\begin{array}{c}\text { Parameters of } \\
\text { Steel Reinforced }\end{array}$} & \multicolumn{3}{|c|}{$\begin{array}{l}\text { Parameters of CFRP } \\
\text { plate }\end{array}$} & \multirow{2}{*}{$\frac{\text { Ratio }}{\underbrace{\frac{0}{4}}_{\frac{\infty}{4}}}$} \\
\hline & & & $\begin{array}{l}\stackrel{\bar{\Xi}}{\Xi} \Xi \\
\stackrel{\Xi}{\Xi}\end{array}$ & $\begin{array}{l}\dot{\bar{\nu}} \\
\text { है } \\
\text { Z }\end{array}$ & 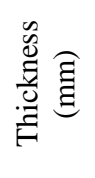 & 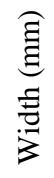 & $\begin{array}{l}\bar{\Xi} \\
\text { है } \\
\text { z }\end{array}$ & \\
\hline \multirow[t]{2}{*}{1} & B1_2A16-R & 30 & 16 & 2 & - & - & - & - \\
\hline & B2_2A16-1S & 30 & 16 & 2 & 1.2 & 25 & 1 & 7.46 \\
\hline \multirow[t]{2}{*}{2} & B3_3A16-R & 30 & 16 & 3 & - & - & - & - \\
\hline & B4_3A16-2S & 30 & 16 & 3 & 1.2 & 25 & 2 & 9.94 \\
\hline \multirow[t]{2}{*}{3} & B5_3A14-R & 30 & 14 & 3 & - & - & - & - \\
\hline & B6_3A14-2S & 30 & 14 & 3 & 1.2 & 25 & 2 & 12.98 \\
\hline \multirow[t]{2}{*}{4} & B7_3A16-R & 30 & 16 & 3 & - & - & - & - \\
\hline & B8_3A16-3S & 30 & 16 & 3 & 1.2 & 25 & 3 & 14.91 \\
\hline \multirow[t]{2}{*}{5} & B9_3A14-R & 30 & 14 & 3 & - & - & - & - \\
\hline & B10_3A14-3S & 30 & 14 & 3 & 1.2 & 25 & 3 & 19.47 \\
\hline \multirow[t]{2}{*}{6} & B11_2A16-R & 30 & 16 & 2 & - & - & - & - \\
\hline & B12_2A16-3S & 30 & 16 & 2 & 1.2 & 25 & 3 & 22.38 \\
\hline
\end{tabular}
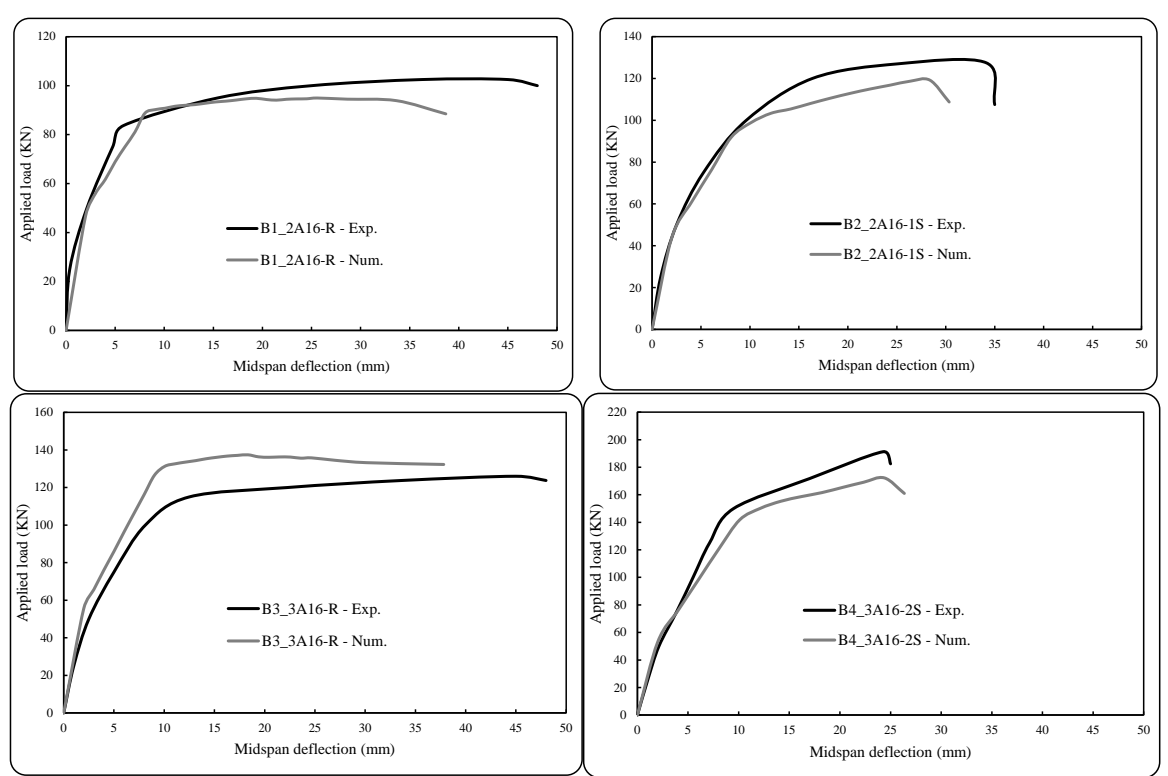

Fig. 6. Comparison between the experimental results and the FE simulation results of the applied load-mid-span deflection response for the beam specimens presented in [11] 

STRENGTHENED WITH NSM-CFRP

Table 3. Comparison of experimental and numerical test results (validation)

\begin{tabular}{|l|c|c|c|c|}
\hline \multirow{2}{*}{ Specimen } & \multicolumn{2}{|c|}{ Peak Loads } & \multicolumn{2}{c|}{ Increase effect } \\
\cline { 2 - 5 } & $\begin{array}{c}\text { Experimental } \\
\text { Hongseob (KN) }\end{array}$ & Numerical (KN) & $\begin{array}{c}\text { Experiental } \\
\text { Hongseob (\%) }\end{array}$ & Numerical (\%) \\
\hline B1_2A16-R & 104.00 & 94.96 & - & - \\
\hline B2_2A16-1S & 129.30 & 119.18 & 24.33 & 25.51 \\
\hline B3_3A16-R & 125.90 & 137.42 & - & - \\
\hline B4_3A16-2S & 191.80 & 176.66 & 52.34 & 28.55 \\
\hline
\end{tabular}
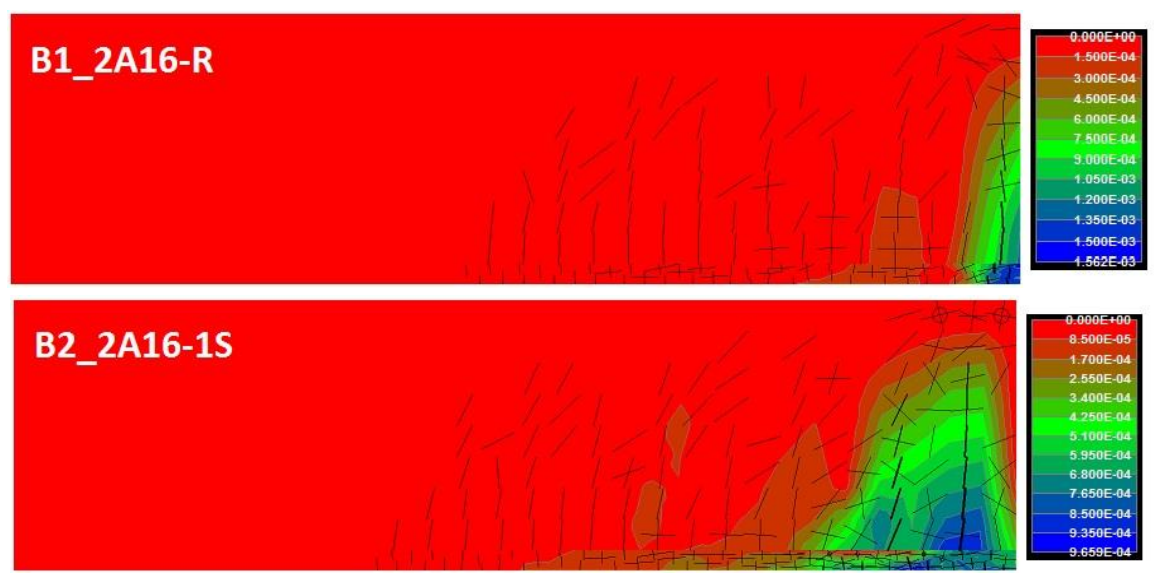

\section{B3_3A16-R}

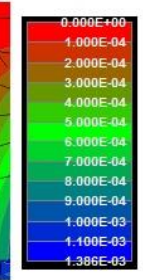

\section{B4_3A16-2S}

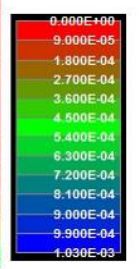

Fig. 7. The Iso values of the mid-span crack width of the validated beam models (mm) 


\subsection{Openings of cracks in beams}

After validation of the beam model, the ATENA 2D calculation code allows us to know the values of the width of the cracks in the beams. It also allows us to see the network of cracking on the mid-spans of the beams modeled. The Fig.7. shows the iso-values of the crack openings which are shown in $(\mathrm{mm})$, it also represents the cracking network and the positioning of the main crack of each beam configuration. It can be seen that the width of the main cracks is small in the reinforced beams compared to the references beams. This is due to the contribution of composite materials in improving the behavior of reinforced concrete beams reinforced by CFRP bending.

\subsection{Effect of the reinforcement ratio Af/As}

The first parameter studied is the reinforcement ratio Af/As. It was given the following values: $7.46 \%, 9.94 \%, 12.98 \%, 14.91 \%, 19.47 \%$ and $22.38 \%$. These represent all the practical situations of the Af/As ratio from small to high. It can be seen in Fig. 8 that all the models seem to behave in the same way but with different ultimate loads. This comparison proves that when the ratio Af/As increases, the capacity of the beams improves. Thus, with the variation of the Af/As ratio from $7.46 \%$ to $22.38 \%$, an increase in the ultimate strength ranging from $25.51 \%$ to $42.89 \%$ is obtained in the groups with the same steel sections Longitudinal. Table 4 summarizes the ultimate load of the modeled beams as well as their percentage increase effects.

\subsection{Effect of the number of strips CFRP}

To see the influence of the number of CFRP strips in the reinforcement of the beams. Different values have been assigned: 1, 2 and 3 CFRP bands but considering the case of beams with the same configuration of the longitudinal steels. All reinforced beams tested have greater rigidity compared to the corresponding reference beams shown in Fig.9, it can be seen that a tendency of the ultimate resistances of the beam patterns tends to increase with the increase in the number of CFRP bands with higher gains for the super-shielded beams. In the case of a beam with higher steel diameters, the final loading capacity is improved, but the ductility is greatly reduced. But the effect of increasing the resistance gain becomes low for over-armed beams which have a large load capacity despite the increase in the number of CFRP bands. It is evident from these results that increasing the reinforcement ratio does not lead to a linear relationship in the effect and this in the case of a lesser compressive strength of te concrete which is of the order of $30 \mathrm{Mpa}$ in this investigation. 

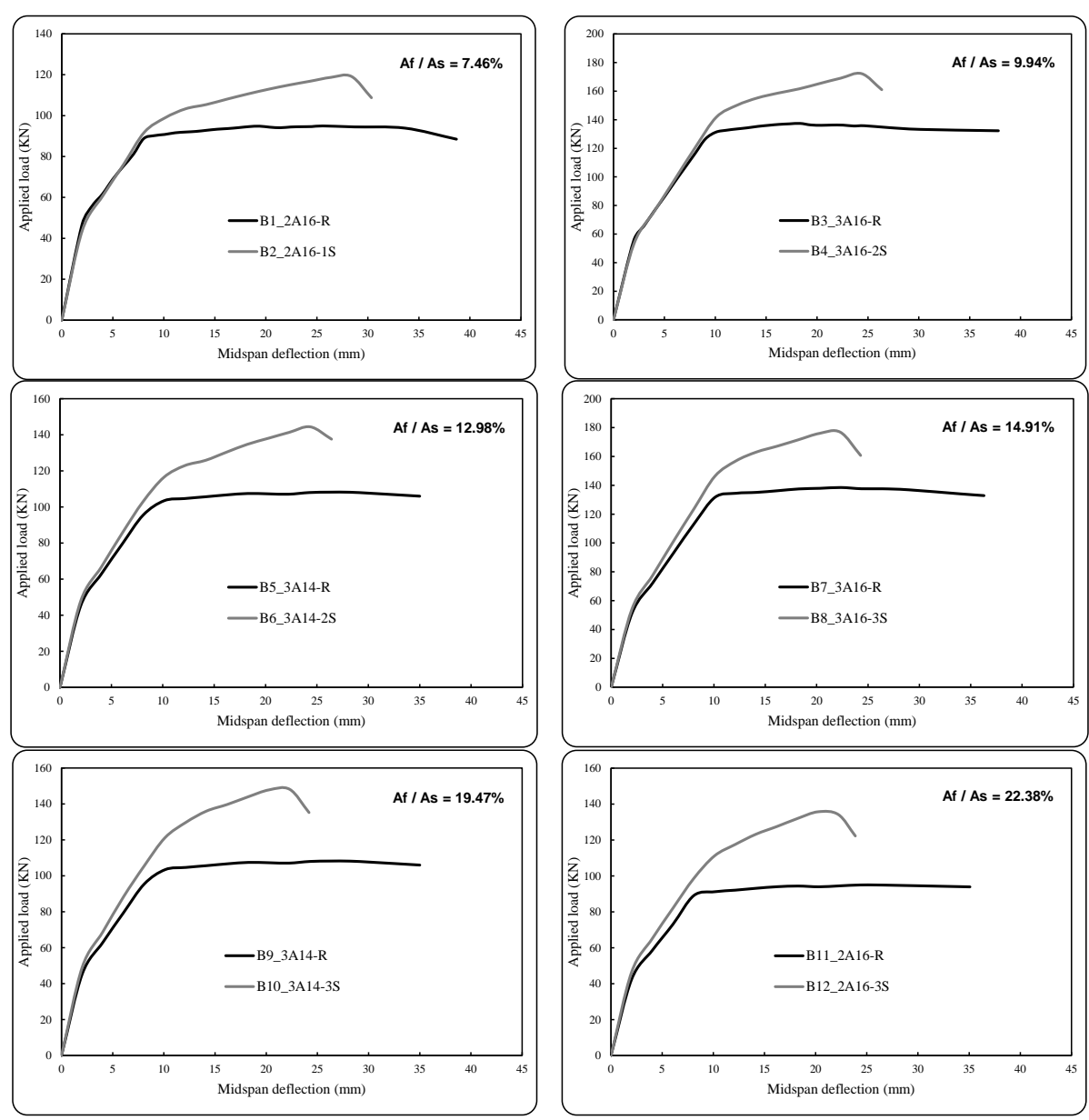

Fig. 8. Effect of variation of the reinforcement ratio Af/As on load-deflection response 
Table 4. Effect of the reinforcement ratio Af/As on the reinforced concrete beams of the parametric study

\begin{tabular}{|c|c|c|c|}
\hline Group & Specimen designation & Peak Loads (KN) & Increase effect in group $(\%)$ \\
\hline \multirow{2}{*}{1} & B1_2A16-R & 94.96 & \multirow{2}{*}{25.51} \\
\hline & B2_2A16-1S & 119.18 & \\
\hline \multirow{2}{*}{2} & B3_3A16-R & 137.42 & \multirow{2}{*}{28.55} \\
\hline & B4_3A16-2S & 176.66 & \\
\hline \multirow{2}{*}{3} & B5_3A14-R & 107.50 & \multirow{2}{*}{34.36} \\
\hline & B6_3A14-2S & 144.44 & \\
\hline \multirow{2}{*}{4} & B7_3A16-R & 138.46 & \multirow{2}{*}{27.72} \\
\hline & B8_3A16-3S & 176.84 & \\
\hline \multirow{2}{*}{5} & B9_3A14-R & 108.24 & \multirow{2}{*}{36.86} \\
\hline & B10_3A14-3S & 148.14 & \\
\hline \multirow{2}{*}{6} & B11_2A16-R & 94.98 & \multirow{2}{*}{42.89} \\
\hline & B12_2A16-3S & 135.72 & \\
\hline
\end{tabular}

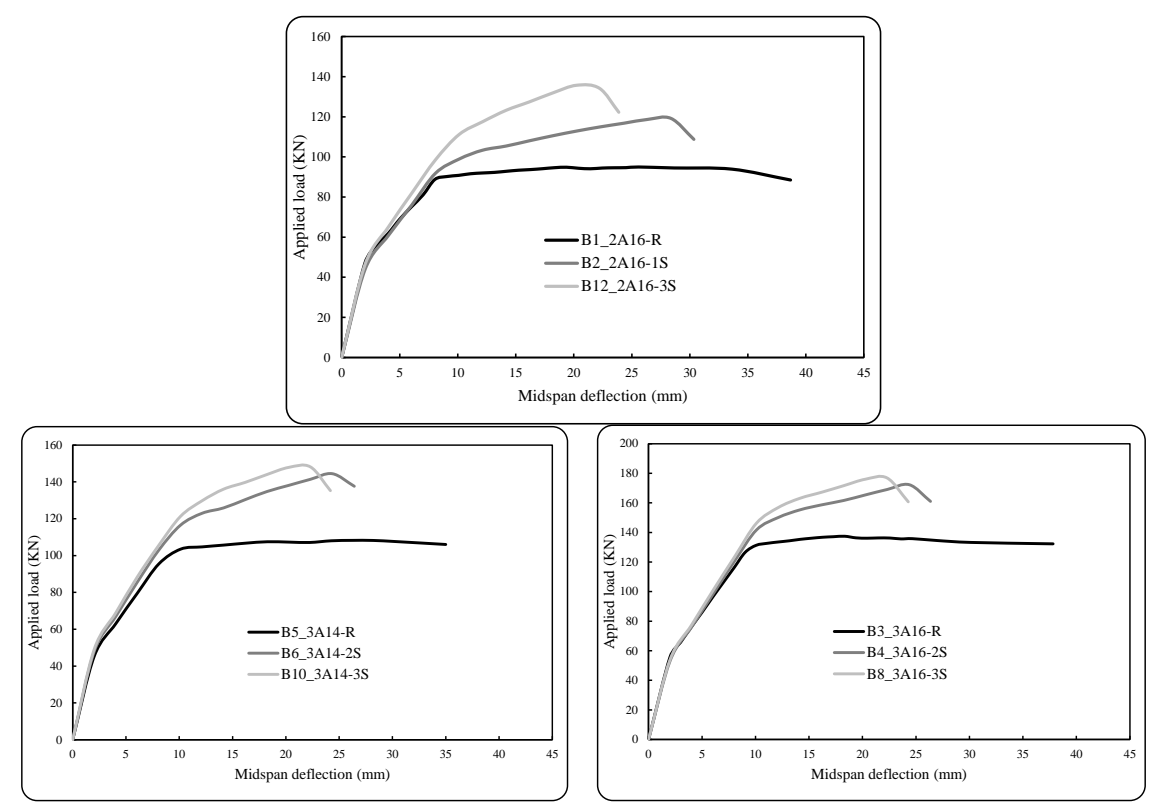

Fig. 9. Effect of variation of CFRP number on load-deflection response 


\section{CONCLUSIONS}

Numerical finite element modeling was conducted to study the performance of strengthened RC beams NSM-CFRP. The model developed was previously validated by comparing the predicted results with the corresponding experimental data, where a good agreement was found. A parametric study was carried out to evaluate the effect of using a different Af/As ratio on the bending performance of reinforced beams. According to the results, the following conclusions can be drawn:

- There is a good concordance between the experimental results and numerical simulations in terms of load-deflection response at all stages of flexural loading until the sample breaks.

- Strengthening reinforced concrete beams with NSM-CFRP strips increases their flexural strength. The numerical results obtained highlighted the performance of innovative composite materials for bending reinforcement.

- With a variation of the Af/As ratio of $7.46 \%$ to $22.38 \%$, an increase in the ultimate strength ranging from $25.51 \%$ to $42.89 \%$ is obtained.

- Overall, the load capacity of the beams improves as the Af/As ratio increases. Strengthening with NSM-CFRP bands improved the performance of beams made with $30 \mathrm{Mpa}$ compression strength concrete in terms of failure load and ductility. However, in the case of a beam having a larger Af/As ratio, the ultimate load capacity is further improved, but the ductility is reduced.

\section{REFERENCES}

1. El-Hacha R., Rizkalla S.H.: Near surface mounted fiber reinforced polymer reinforcements for flexural strengthening of concrete structures, in: ACI Structural Journal, 101, 5 (2004) 717-726.

2. Kotynia R.: Analysis of the flexural response of NSM FRP Strengthened concrete beams, in proc. of the FRPRCS-8 Symposium, Patras, Greece, 16-18 July (2007) $1-10$.

3. Soliman S.M., El-Salakawy E., Benmokrane B.: Flexural behaviour of concrete beams strengthened with near sur-face mounted FRP bars, in: Fourth International Conference on FRP Composites in Civil Engineering (CICE2008), Zurich, Switzerland, 22-24 July (2008) 1-6.

4. Al-Mahmoud F., Castel A., François R.L., Tourneur C.: RC beams strengthened with NSM CFRP rods and modeling of peeling-off failure, in Composite Structures, 92, Jul (2010) 1923-1930.

5. Hong K.N., Han J.W., Seo D.W., Han S.H.: Flexural response of reinforced concrete members strengthened with near-surfaced-mounted CFRP strips, in International Journal of the Physical Sciences, 6, 5, 4 March (2011) 948-961. 
6. Mostofinejad D., Moghaddas A.: Bond efficiency of EBR and EBROG methods in different flexural failure mechanisms of FRP strengthened RC beams, in Construction and Building Materials, 54 (2014) 605-614.

7. Sharaky I.A., Torres, L., Sallam, H.E.M.: Experimental and analytical investigation into the flexural performance of $R C$ beams with partially and fully bonded NSM FRP bars/strips, in Composite Structures, 122, (2015) 113-126.

8. Haddad R.H., Almomani, O.A.: Recovering flexural performance of thermally damaged concrete beams using NSM CFRP strips, in Construction and Building Materials, 154 (2017) 632-643.

9. Cervenka V., Jendele L., Cervenka J.: Atena Program Documentation. Part. 1. Theory, ed. 2010, Prague, Cervenka Consulting Ltd.

10. Hongseob O., Jongsung S., Minkwan J., Hyunjoong K.: The evaluation of structural performance for RC beams strengthened by NSM using CFRP plate, in Proc. Second Official International Conference of International Institute for FRP in Construction for Asia-Pacific Region, Seoul, South Korea, 9-11 December (2009) 525-532.

11. Khene A., Chikh N., Mesbah H.A.: Numerical modeling of reinforced concrete beams strengthened by NSM-CFRP technique, in Proc. Third International Conference on Architecture, Structure and Civil Engineering, London, U.K., 2627 July (2016) 30-36.

\section{NUMERYCZNA ANALIZA ZGINANIA BELEK ŻELBETOWYCH WZMOCNIONYCH KOMPOZYTAMI WŁÓKNISTYMI WKLEJANYMI W OTULINĘ BETONOWĄ}

\section{Streszczenie}

$\mathrm{W}$ badaniach przedstawionych $\mathrm{w}$ pracy zastosowano nową technikę zbrojenia materiałami kompozytowymi poprzez wklejanie ich w otulinę betonową (NSM near surface mounted). Technika NSM polega na wprowadzeniu pasków laminatu $\mathrm{z}$ polimeru wzmocnionego włóknami węglowymi (CFRP) do szczelin wykonanych wcześniej na poziomie powłoki betonowej wzmacnianych elementów. Przeprowadzono badania numeryczne na prostokątnych belkach żelbetowych wzmocnionych NSM-CFRP z wykorzystaniem kodu elementów skończonych ATENA. W badaniach tych przeprowadzono również badanie parametryczne. Wyniki numeryczne porównano z wynikami eksperymentalnymi belek testowanych przez innych badaczy o tych samych konfiguracjach zbrojenia. Wyniki numeryczne są zgodne z eksperymentalnymi, a studium parametryczne prowadzi to ciekawych wniosków.

Słowa kluczowe: NSM, wzmocnienie, CFRP, analiza numeryczna, belki żelbetowe 